\title{
RADIOACTIVE XENON $\left({ }^{133} \mathrm{Xe}\right)$ DISAPPEARANCE RATES FROM THE SYNOVIAL CAVITY OF THE HUMAN KNEE JOINT IN NORMAL AND ARTHRITIC SUBJECTS
}

BY

\author{
R. A. ST. ONGE*, W. C. DICK, G. BELL, AND J. A. BOYLE \\ From the Centre for Rheumatic Diseases and the University Department of Medicine, Glasgow
}

Radiosodium (Jacox, Johnson, and Koontz, 1952; Harris and Millard, 1956; Davidson and Wisham, 1958, Harris, Millard, and Banerjee, 1958; Scholer, Lee, and Polley, 1959), deuterium (Scholer and others, 1959), and radioiodinated human and rabbit serum albumin (Ahlström, Gedda, and Hedberg, 1956; Rodnan and MacLachlan, 1960) have been used to determine "clearance" rates from joints. All these substances have the disadvantage of being recirculated into the joint after passing into the blood stream and of being biologically active.

We considered that radioactive Xenon $\left({ }^{133} \mathrm{Xe}\right)$ might overcome these difficulties. Xenon is a gas with a high blood/air partition coefficient which is approximately 95 per cent. expired in one circulation through the lungs (Lassen, 1963; Lassen, Lindbjerg, and Munck, 1964). Xenon is biologically inert and passes across cell membranes in adherence to laws of diffusion gradient and solubility; it also possesses the advantage of being a "soft" gamma emitter and exposes both patient and investigator to low radiation dosage (Lassen, 1963).

In this preliminary report we have compared the rates of disappearance of ${ }^{133} \mathrm{Xe}$ from normal knee joints and from the actively involved knees of patients with rheumatoid arthritis (RA). We have found that the rates of disappearance of ${ }^{133} \mathrm{Xe}$ are clearly different in normal and rheumatoid knees.

\footnotetext{
* Presently at Yale University School of Medicine, New Haven, Connecticut, U.S.A. This investigation was conducted in partial fulfilment of the requirements for the M.D. candidates thesis of Yale University School of Medicine, R.A.St.O.
}

Patients

Studies were performed on fourteen clinically active knee joints of six patients (4 male and 2 female) with "definite" or "classical" sero-positive RA (Ropes, Bennett, Cobb, Jacox, and Jessar, 1956). Erosions were present on joint $x$ ray in all six patients, all but one patient having erosions in the knees. One patient had repeat studies performed in both knees.

Seven studies were performed on four healthy male volunteers.

\section{Technique of ${ }^{133}$ Xe Knee Joint Injections}

Using full aseptic technique, approximately $10 \mu \mathrm{c}$. ${ }^{133} \mathrm{Xe}$ in $1.5 \mathrm{ml} .0 .9$ per cent. $\mathrm{NaCl}$ were injected into the knee joint by a lateral infra-patellar approach. All the subjects were comfortably reclined on a firm bed and the room temperature remained constant.

The joint was aspirated as fully as possible before the ${ }^{133} \mathrm{Xe}$ was injected. Immediately after injection the patient was asked to flex and extend the knee joint a few times in order to ensure uniform distribution of radioactivity. The lower limb was then immobilized by sand bags in an extended position level with the heart.

A lightly collimated $1.5^{\prime \prime}$ sodium iodide scintillation crystal was connected to an Ecko ratemeter and a direct writing pen recorder. The crystal was directed at the lateral aspect of the knee joint using the border of the patella as the upper reference point.

Counts per minute were taken over the ranges of 1,000 to 10,000 ; the back-ground was of the order of 10 to $30 \mathrm{cpm}$.

Measurements started 2 minutes after injection and were taken continuously for 30 to 45 minutes at a paper speed of $600 \mathrm{~mm}$. $/ \mathrm{hr}$. The graph was sampled at 1 -minute intervals for count rates and these were transposed on to semi-logarithmic paper. The biological half-life was then calculated $\left(\mathrm{T} \frac{1}{2}\right)$. 


\section{Results}

The results are shown in the Table and in Figs 1 to 3 .

TABLE

BIOLOGICAL HALF-LIVES OF DISAPPEARANCE CURVES OF ${ }^{132} \mathrm{Xe}$ FROM KNEE JOINT CAVITIES

\begin{tabular}{|c|c|c|c|}
\hline \multirow{2}{*}{ Series $\quad \cdots \quad \ldots$} & \multicolumn{2}{|c|}{$\begin{array}{l}\text { Patients with } \\
\text { Rheumatoid Arthritis }\end{array}$} & \multirow{2}{*}{$\begin{array}{c}\begin{array}{r}\text { Normal } \\
\text { Subjects }\end{array} \\
T_{\frac{1}{2}}^{*}\end{array}$} \\
\hline & $T^{\prime} \frac{1}{2} \dagger$ & $T_{\frac{1}{2}} *$ & \\
\hline $\begin{array}{l}\text { Biological } \\
\text { Half-lives } \\
\text { (min.) }\end{array}$ & $\begin{array}{l}3 \cdot 0 \\
3 \cdot 4 \\
3 \cdot 6 \\
2 \cdot 0 \\
3 \cdot 2 \\
3 \cdot 0 \\
3 \cdot 2(3 \cdot 0) \\
2 \cdot 6(2 \cdot 4) \\
1 \cdot 8 \\
6 \cdot 4 \\
2 \cdot 7 \\
2 \cdot 2\end{array}$ & $\begin{array}{l}42 \cdot 0 \\
61 \cdot 2 \\
19 \cdot 2 \\
24 \cdot 5 \\
40 \cdot 0 \\
57 \cdot 0 \\
29 \cdot 5(28 \cdot 0) \\
35 \cdot 0(30 \cdot 0) \\
50 \cdot 0 \\
50 \cdot 0 \\
26 \cdot 6 \\
27 \cdot 0\end{array}$ & $\begin{array}{r}630 \\
120 \\
150 \\
66 \\
264 \\
120 \\
175\end{array}$ \\
\hline $\begin{array}{l}\text { Range } \\
\text { Mean } \\
\text { Standard Error } \\
\text { of Mean }\end{array}$ & $\begin{array}{r}1 \cdot 8-6 \cdot 4 \\
3 \cdot 4 \\
0 \cdot 35\end{array}$ & $\begin{array}{c}19 \cdot 2-61 \cdot 2 \\
38 \cdot 0 \\
5 \cdot 17\end{array}$ & $\begin{array}{r}66-630 \\
217 \cdot 85 \\
22 \cdot 6\end{array}$ \\
\hline
\end{tabular}

*Tt is the biological half-life of the slow exponential curve in patients with RA (Fig. 1) or the mono-exponential curve in normal subjects (Fig. 3).

$+T^{\prime}{ }^{\prime}$ is the biological half-life of the fast exponential curve in patients with RA (Fig. 2).

In all the patients with RA a bi-exponential mode of disappearance of ${ }^{133} \mathrm{Xe}$ from the knee joint was observed. Fig. 1 shows a typical example. The count rate has been plotted at 1-minute intervals on semi-log graph paper and there is an exponential (straight line) component to this curve beginning approximately 15 minutes after injection. Fig. 2 shows a semi-log plot of the difference between the straight line in Fig. 1 and the points recorded during the first 15 minutes or so of the experiment. The second semi-log plot again describes a fairly straight line. The biological half-life was calculated for each of the two exponential functions. $T \frac{1}{2}$ refers to the biological half-life of the slower component

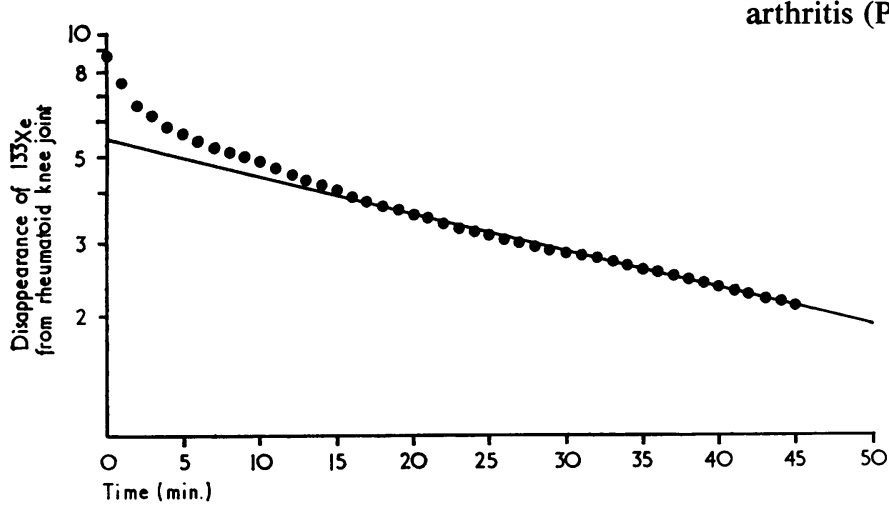

of the bi-exponential curve of which a representative $\frac{7}{T}$ example is shown in Fig. 1 . $T^{\prime} \frac{1}{2}$ refers to the biological half-life of the faster component of the 3 bi-exponential curve (Fig. 2).

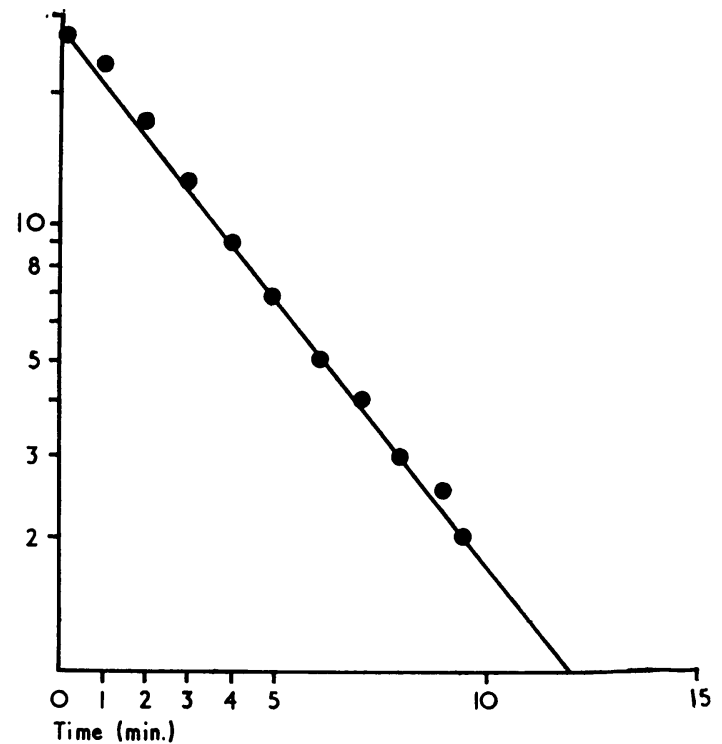

Fig. 2.-Semi-log plot of the difference between the points plotted in the first 15 minutes after injection of ${ }^{133} \mathrm{Xe}$ and the straight line shown $\infty$ in Fig. 1.

The Table shows the individual results obtaineg for $T^{\frac{1}{2}}$ and $T^{\prime} \frac{1}{2}$ in the knees of the six patients with RA. The mean and standard error of $T \frac{1}{2}$ for these patients was $38 \pm 5 \cdot 17$ minutes and for $T^{\prime} \frac{1}{2}$ $3 \cdot 4 \pm 0 \cdot 35$ minutes.

The findings in all the subjects with normal knees differed from those observed in the arthritic patients. Normal subjects displayed a mono-exponential disappearance rate (Fig. 3). The mean $\mathrm{T} \frac{1}{2}$ (Table) was much slower $(217 \cdot 85 \pm 22 \cdot 6$ minutes; range 66 ? to 630 ). This mean value is highly significantly different from that of the patients with rheumatoid arthritis $(\mathrm{P}<0.001)$.

Fig. 1.-Typical semi-log plot of the disappearance curve of ${ }^{130} \mathrm{Xe}$ from the knee joint cavity of a patient with rheumatoid arthritis. 


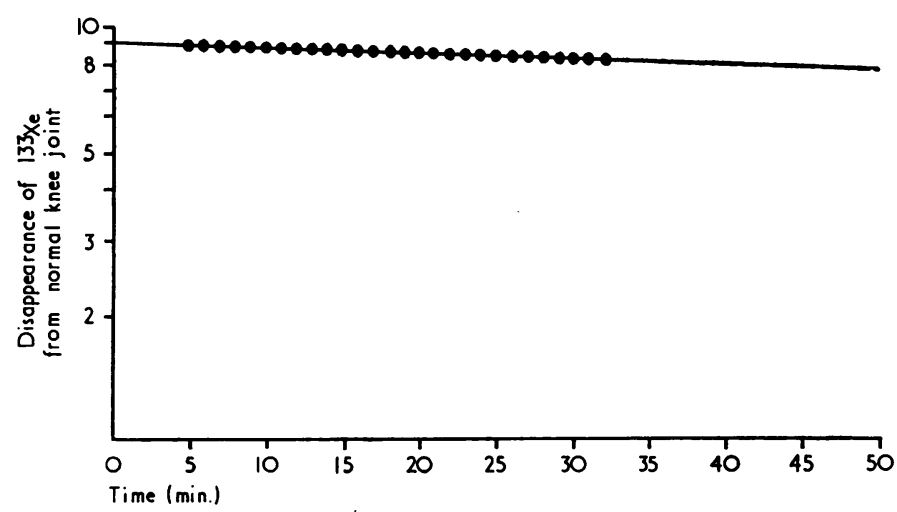

Fig. 3.-Typical semi-log plot of a disappearance curve of ${ }^{133} \mathrm{Xe}$ from a normal knee joint. The curve is monoexponential as shown by the straight line on semi-log graph paper.

A normal knee joint was injected with $100 \mu \mathrm{c}$. ${ }^{133} \mathrm{Xe}$ in $20 \mathrm{ml}$. carrier normal saline and a value of 66 minutes was found for $T \frac{1}{2}$. This is the lowest value obtained for a normal knee and suggests that the volume of fluid injected into the knee joint may in part determine the rate of disappearance of ${ }^{133} \mathrm{Xe}$.

The technique appears to give reproducible results. The Table includes the results of repeat studies performed in both knees of one patient with rheumatoid arthritis. The inter-observer error in sampling the graph for count rates and in subsequent calculation of $T \frac{1}{2}$ and $T^{\prime} \frac{1}{2}$ has been studied and is very low.

In order to assess the effect of the volume of synovial fluid on the rate of disappearance of ${ }^{133} \mathrm{Xe}$ from the knee joint, measurements were made in two rheumatoid patients before and after the removal of synovial fluid. The $T \frac{1}{2}$ before and after the removal of $40 \mathrm{ml}$. from the knee of one of the patients was 68 and 66 minutes respectively, and after the removal of $51 \mathrm{ml}$. of synovial fluid from the other patient 56 and 50 minutes.

\section{Discussion}

The results show that there are marked differences between the rates of disappearance of ${ }^{133} \mathrm{Xe}$ from the knee joints of patients with active RA and normal knee joints. Indeed, there is no overlap between the ranges of $T_{\frac{1}{2}}$ values for normal and abnormal knee joints with the data so far collected. Moreover, in all the patients with active RA, the curve of ${ }^{133} \mathrm{Xe}$ disappearance has consistently proved to be a bi-exponential function, which may be described by:

$$
\begin{aligned}
& \text { where } \begin{aligned}
y & =K e-\lambda t+K^{\prime} e-\lambda^{\prime} t \\
\lambda & =\frac{0.693}{\mathrm{~T}_{\frac{1}{2}}}
\end{aligned} \\
& \text { and } \quad \lambda^{\prime}=\frac{0.693}{T^{\prime} \frac{1}{2}}
\end{aligned}
$$

In all normal knees we observed a mono-exponential rate of disappearance of ${ }^{133} \mathrm{Xe}$ from the joint.

Other workers (Harris and Millard, 1956; Harris and others, 1958; Scholer and others, 1959) have observed a mono-exponential rate of disappearance of different substances from the joint cavity in RA, but to our knowledge none has described a biexponential disappearance curve in RA. The reasons for the bi-exponential pattern of ${ }^{133} \mathrm{Xe}$ disappearance are not known at this time.

Scholer and others (1959) have shown that the concentration of $\mathrm{D}_{2} \mathrm{O}$ and of ${ }^{24} \mathrm{Na}$ in the blood stream rises as these substances are removed from the joint. We have also demonstrated ${ }^{133} \mathrm{Xe}$ in the femoral vein of a normal patient while the isotope was disappearing from the knee, and it seems reasonable to conclude that the mono-exponential rate of disappearance of ${ }^{133} \mathrm{Xe}$ from the normal knee is accounted for by passage of the isotope into the blood stream.

It seems a reasonable hypothesis that the slower exponential component of the bi-exponential curve displayed patients with RA may be accounted for by a similar mechanism, and that the shorter biological half-life of this component compared with the half-life of the mono-exponential curve in normal subjects reflects a greatly enhanced blood flow through the inflamed synovium in cases of RA.

The mechanism underlying the fast exponential component of the bi-exponential curve of ${ }^{133} \mathrm{Xe}$ disappearance in patients with RA (Fig. 2) is more problematical. One possibility is that this fast component is an artefact, but the question then arises why this artefact has not been seen in normal subjects. Further work on this fast exponential component in RA seems to be indicated.

The ${ }^{133}$ Xe disappearance technique, although not new (Lassen, 1963; Lassen and others, 1964), has not previously been applied to the study of joint 
physiology and pathology. The isotope would appear to be ideal for this purpose because, unlike other substances whose disappearance rates from the synovial cavity have been studied, it is biologically inert.

\section{Summary}

Studies of the disappearance rates of radioactive
Xenon $\left({ }^{133} \mathrm{Xe}\right)$ from the cavity of the knee joint after intra-articular injection of the isotope have shown a bi-exponential pattern of isotope disappearance in patients with active rheumatoid arthritis. A mono- on exponential pattern of ${ }^{133} \mathrm{Xe}$ disappearance from the $\overrightarrow{\vec{F}}$ knee joints of healthy subjects was observed. ${ }^{133} \mathrm{Xe} \stackrel{\text { S }}{\stackrel{9}{9}}$ disappears much more rapidly from diseased than from normal knees.

\section{REFERENCES}

Ahlström, S., Gedda, P. O., and Hedberg, H. (1956). Acta rheum. scand., 2, 129 (Disappearance of radioactive serum albumin from joints in rheumatoid arthritis).

Davidson, S., and Wisham, L. H. (1958). J. clin. Invest., 37, 389 (The clearance of $\mathrm{Na}^{24}$ from the normal and osteoarthritic knee joint and the response to intra-arterial priscoline).

Harris, R., and Millard, J. B. (1956). Clin. Sci., 15, 9 (Clearance of radioactive sodium from the knee joint).

- - - and Banerjee, S. K. (1958). Ann. rheum. Dis., 17, 189 (Radiosodium clearance from the knee joint in rheumatoid arthritis).

Jacox, R. F., Johnson, M. K., and Koontz, R. (1952). Proc. Soc. exp. Biol. (N.Y.), 80, 655 (Transport of radioactive sodium across the synovial membrane of normal human subjects).

Lassen, N. A. (1963). "VIII Conf. Ital. Soc. Biol. Med., Pisa, 1963".

- Lindbjerg, J., and Munck, O. (1964). Lancet, 1, 686 (Measurement of blood-flow through skeletal muscle by the intramuscular injection of Xenon ${ }^{133}$ ).

Rodnan, G. P., and MacLachlan, M. J. (1960). Arthr. and Rheum., 3, 152 (The absorption of serum albumin and gamma globulin from the knee joint of man and rabbit).

Ropes, M. W., Bennett, G. A., Cobb, S., Jacox, R., and Jessar, R. A. (1956). Bull. rheum. Dis., 7, 121 (Proposed diagnostic criteria for rheumatoid arthritis).

Scholer, J. F., Lee, P. R., and Polley, H. F. (1959). Arthr. and Rheum., 2, 426 (The absorption of heavy water and radioactive sodium from the knee joint of normal persons and patients with rheumatoid arthritis).

Les taux de disparition du xénon radioactif $\left({ }^{133} \mathrm{Xe}\right)$ de l'articulation du genou humain chez des sujets arthritiques et normaux

\section{RÉSUMÉ}

Les études des taux de disparition du xénon radioactif (133Xe) de la cavité articulare du genou après injection intra-articulaire de ce isotope ont montré un tableau bi-exponentiel de sa disparition chez des malades atteints de polyarthrite rhumatoïde active. Chez des sujets normaux cette disparition n'était que mono-exponentielle, ce qui montre que le ${ }^{133} \mathrm{Xe}$ disparaît beaucoup plus vite des genoux malades que des genoux normaux.
La velocidad de desparición del xenón radioactivo (133Xe) de la articulación de la rodilla humana en sujetos artriticos y normales

\section{SUMARIO}

Los estudios de la velocidad de desaparición del xenón radioactivo $\left({ }^{133} \mathrm{Xe}\right)$ de la cavidad articular de la rodilla después de su inyección intra-articular reverlaron un cuadro biexponencial de esta desaparición en enfermoscon? poliartritis reumatoide activa. En sujetos normales el윽 cuadro de desaparición fué monoexponencial, lo que.demuestra que el ${ }^{133} \mathrm{Xe}$ desaparece mucho más rapidamente de rodillas enfermas que de las sanas. 